\title{
Front Matter: Volume 7650
}

, "Front Matter: Volume 7650," Proc. SPIE 7650, Health Monitoring of Structural and Biological Systems 2010, 765001 (29 April 2010); doi: 10.1117/12.865246

SPIE Event: SPIE Smart Structures and Materials + Nondestructive Evaluation and SPIE. Health Monitoring, 2010, San Diego, California, United States 


\title{
PROCEEDINGS OF SPIE
}

\section{Health Monitoring of Structural and Biological Systems 2010}

\author{
Tribikram Kundu \\ Editor \\ 8-11 March 2010 \\ San Diego, California, United States \\ Sponsored by \\ SPIE \\ Cosponsored by \\ American Society of Mechanical Engineers (United States) \\ Cooperating Organizations \\ Intelligent Materials Forum (Japan) \\ Jet Propulsion Laboratory (United States) \\ National Science Foundation (United States) \\ Published by \\ SPIE
}

Part One of Two Parts

Volume 7650 
The papers included in this volume were part of the technical conference cited on the cover and title page. Papers were selected and subject to review by the editors and conference program committee. Some conference presentations may not be available for publication. The papers published in these proceedings reflect the work and thoughts of the authors and are published herein as submitted. The publisher is not responsible for the validity of the information or for any outcomes resulting from reliance thereon.

Please use the following format to cite material from this book:

Author(s), "Title of Paper," in Health Monitoring of Structural and Biological Systems 2010, edited by Tribikram Kundu, Proceedings of SPIE Vol. 7650 (SPIE, Bellingham, WA, 2010) Article CID Number.

ISSN 0277-786X

ISBN 9780819480651

Published by

SPIE

P.O. Box 10, Bellingham, Washington 98227-0010 USA

Telephone +1 3606763290 (Pacific Time) · Fax +1 3606471445

SPIE.org

Copyright (c) 2010, Society of Photo-Optical Instrumentation Engineers

Copying of material in this book for internal or personal use, or for the internal or personal use of specific clients, beyond the fair use provisions granted by the U.S. Copyright Law is authorized by SPIE subject to payment of copying fees. The Transactional Reporting Service base fee for this volume is $\$ 18.00$ per article (or portion thereof), which should be paid directly to the Copyright Clearance Center (CCC), 222 Rosewood Drive, Danvers, MA 01923. Payment may also be made electronically through CCC Online at copyright.com. Other copying for republication, resale, advertising or promotion, or any form of systematic or multiple reproduction of any material in this book is prohibited except with permission in writing from the publisher. The CCC fee code is 0277-786X/10/\$18.00.

Printed in the United States of America.

Publication of record for individual papers is online in the SPIE Digital Library.

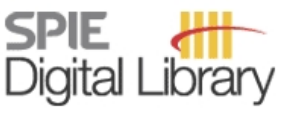

SPIEDigitalLibrary.org

Paper Numbering: Proceedings of SPIE follow an e-First publication model, with papers published first online and then in print and on CD-ROM. Papers are published as they are submitted and meet publication criteria. A unique, consistent, permanent citation identifier (CID) number is assigned to each article at the time of the first publication. Utilization of CIDs allows articles to be fully citable as soon they are published online, and connects the same identifier to all online, print, and electronic versions of the publication. SPIE uses a six-digit CID article numbering system in which:

- The first four digits correspond to the SPIE volume number.

- The last two digits indicate publication order within the volume using a Base 36 numbering system employing both numerals and letters. These two-number sets start with 00, 01, 02, 03, 04 , $05,06,07,08,09,0 A, 0 B \ldots$. OZ, followed by 10-1Z, 20-2Z, etc.

The CID number appears on each page of the manuscript. The complete citation is used on the first page, and an abbreviated version on subsequent pages. Numbers in the index correspond to the last two digits of the six-digit CID number. 


\title{
Contents
}

\section{Part One}

\author{
xv Conference Committee \\ xix Introduction
}

SESSION 1 GUIDED WAVES I: SIGNAL GENERATION AND ANALYSIS

765003 A comparison of 1D and 3D laser vibrometry measurements of Lamb waves [7650-01] E. D. Swenson, Air Force Institute of Technology (United States); H. Sohn, KAIST (Korea, Republic of); S. E. Olson, M. P. DeSimio, Univ. of Dayton Research Institute (United States)

765004 Time series predictive models of piezoelectric active-sensing for SHM applications [7650-02] G. Park, E. Figueiredo, K. M. Farinholt, C. R. Farrar, Los Alamos National Lab. (United States)

765005 Detection of delamination defects in carbon fiber reinforced polymer components: miniaturized hardware design for the smart material actuation of ultrasound guided waves [7650-03]

H. Wernick, A. Dantele, T. Rittenschober, J. Korak, PROFACTOR GmbH (Austria)

765006 Lamb wave sensing with metal-core piezoelectric fiber for structural health monitoring [7650-04]

J. Liu, J. Qiu, W. Chang, H. Ji, K. Zhu, Nanjing Univ. of Aeronautics and Astronautics (China)

\section{SESSION 1B BRIDGE MONITORING}

765007 Impact force identification on isotropic and composite panels [7650-05]

I. Bartoli, S. Salamone, Univ. of California, San Diego (United States); M. Mezzanotte, Univ. degli Studi di Palermo (Italy); F. Lanza di Scalea, H. Kim, J. Rhymer, Univ. of California, San Diego (United States)

765008 Bridge monitoring using heterogeneous wireless sensor network [7650-06] S. Haran, S. Kher, Arkansas State Univ. (United States); V. Mehndiratta, Krishna Institute of Engineering and Technology (India)

7650 OA Research of diagnosis sensors fault based on correlation analysis of the bridge structural health monitoring system [7650-08]

S. Hu, W. Chen, L. Liu, X. Gao, Chongqing Univ. (China)

\section{SESSION 2A GUIDED WAVES II: SIGNAL GENERATION AND ANALYSIS}

7650 OB Use of anisotropy to guide acoustic waves along desired trajectories [7650-09]

A. Tehranian, A. V. Amirkhizi, S. Nemat-Nasser, Univ. of California, San Diego (United States) 
7650 OC A new algorithm for detecting impact point in anisotropic plates by the acoustic emission technique [7650-10]

T. Hajzargarbashi, T. Kundu, The Univ. of Arizona (United States); S. Bland, NextGen

Aeronautics Inc. (United States)

7650 OD Mode selective excitation and detection of Lamb waves [7650-11]

K. Hahn, U. Amjad, K. S. Tarar, D. Jha, W. Grill, Univ. Leipzig (Germany)

7650 OE Active loose bolt detection in a complex satellite structure [7650-12]

W. D. Reynolds, D. Doyle, B. Arritt, Air Force Research Lab. (United States)

$7650 \mathrm{OF}$ Warped frequency transform for damage detection using Lamb waves [7650-13]

L. De Marchi, Univ. di Bologna (Italy); M. Ruzzene, B. Xu, Georgia Institute of Technology

(United States); E. Baravelli, A. Marzani, N. Speciale, Univ. di Bologna (Italy)

SESSION 2B SIGNAL PROCESSING AND MODELING

7650 OG A structural transmissibility measurements-based approach for system damage detection [7650-14]

Z. Mao, M. Todd, Univ. of California, San Diego (United States)

$7650 \mathrm{OH}$ Damage inspection and health monitoring of dynamical systems by advanced time-frequency analysis [7650-15]

P. F. Pai, Univ. of Missouri-Columbia (United States); G. Wu, Northwesten Polytechnical Univ. (China); X. Qian, Harbin Institute of Technology (China)

7650 ol Lumped circuit mechanical models and lattice dynamics approach to the dependence of the time-of-flight of bulk and guided acoustical modes on elongation [7650-16]

K. S. Tarar, U. Amjad, W. Grill, Univ. Leipzig (Germany)

7650 0J Characterization of fretting related acoustic emission signals [7650-17]

M. T. Alam, M. Sundaresan, North Carolina Agricultural and Technical State Univ. (United States)

SESSION 3A GUIDED WAVES III: DAMAGE DETECTION

$7650 \mathrm{OL}$ Damage visualization via beamforming of frequency-wavenumber filtered wavefield data [7650-19]

M. Ruzzene, B. XU, S. J. Lee, T. E. Michaels, J. E. Michaels, Georgia Institute of Technology (United States)

7650 OM Computational Lamb wave model validation using 1D and 3D laser vibrometer measurements [7650-20]

S. E. Olson, M. P. DeSimio, M. J. Davies, Univ. of Dayton Research Institute (United States);

E. D. Swenson, Air Force Institute of Technology (United States); H. Sohn, KAIST (Korea,

Republic of) 
7650 ON In situ PZT diagnostics using linear reciprocity under environmental and structural variations [7650-21]

S. J. Lee, J. E. Michaels, T. E. Michaels, Georgia Institute of Technology (United States);

H. Sohn, KAIST (Korea, Republic of)

765000 Guided waves for SHM of a large truss structure [7650-22]

X. P. Zhu, P. Rizzo, Univ. of Pittsburgh (United States); J. Bruck, Pennsylvania State Dept. of Transportation (United States)

7650 OP Delamination detection in composite structures using laser vibrometer measurement of Lamb waves [7650-23]

H. Sohn, KAIST (Korea, Republic of); E. D. Swenson, Air Force Institute of Technology (United

States); S. E. Olson, M. P. DeSimio, Univ. of Dayton Research Institute (United States); D. Dutta, Carnegie Mellon Univ. (United States)

$76500 Q \quad$ Reference-free impedance-based crack detection in plate-like structures [7650-24]

M. Kim, KAIST (Korea, Republic of); E. Kim, H. Park, Dong-A Univ. (Korea, Republic of);

H. Sohn, KAIST (Korea, Republic of)

7650 OR Defect detection using a new ultrasonic guided wave modal analysis technique (UMAT) [7650-25]

F. Yan, FBS Inc. (United States); J. L. Rose, FBS Inc. (United States) and The Pennsylvania State Univ. (United States)

\section{SESSION 3B CIVIL STRUCTURE AND PIPE MONITORING}

7650 OS In-service monitoring of steam pipe systems at high temperatures [7650-26]

Y. Bar-Cohen, S.-S. Lih, M. Badescu, X. Bao, S. Sherrit, S. Widholm, J. Scott, J. Blosiu, Jet

Propulsion Lab. (United States)

7650 OU Behavior of full-scale concrete segmented pipelines under permanent ground displacements [7650-28]

J. Kim, S. O'Connor, S. Nadukuru, J. P. Lynch, R. Michalowski, Univ. of Michigan (United States); R. A. Green, Virginia Polytechnic Institute and State Univ. (United States); M. Pour-Ghaz, W. J. Weiss, Purdue Univ. (United States); A. Bradshaw, Merrimack College (United States)

7650 OV Rayleigh surface waves for characterization of the air void system in fresh concrete [7650-29]

C. J. Lissenden, R. B. Then, S. Li, C. Xiao, M. Lopez de Murphy, J. L. Rose, The Pennsylvania State Univ. (United States)

7650 OW Shear wave velocity profiling and evaluation of liquefaction potential in Northeast Arkansas using simplified equipment [7650-30]

A. Elsayed, S. Haran, Arkansas State Univ. (United States)

7650 0X Health monitoring of concrete piles using piezoceramic-based smart aggregates [7650-31] G. Song, H. Gu, Y. L. Mo, Univ. of Houston (United States); R. Wang, Wuhan Univ. (China) 
7650 oY On-track testing of a power harvesting device for railroad track health monitoring [7650-32] S. E. Hansen, A. Pourghodrat, C. A. Nelson, Univ. of Nebraska-Lincoln (United States); M. Fateh, Federal Railroad Administration (United States)

\section{SESSION 4A ENERGY HARVESTING AND LOW-POWERED SYSTEMS}

765010 A self-powered wireless sensor node for structural health monitoring [7650-34]

D. Zhou, N. Kong, D. S. Ha, D. J. Inman, Virginia Polytechnic Institute and State Univ. (United States)

765011 Autonomous self-powered structural health monitoring system [7650-35] X. P. Qing, Acellent Technologies, Inc. (United States); S. R. Anton, Virginia Polytechnic Institute and State Univ. (United States); D. Zhang, A. Kumar, Acellent Technologies, Inc. (United States); D. J. Inman, Virginia Polytechnic Institute and State Univ. (United States); T. K. Ooi, Univ. of Alabama in Huntsville (United States)

765012 Mathematical model for power output from a plate type energy harvester [7650-36] S. Banerjee, Univ. of Arizona (United States) and Acellent Technologies, Inc. (United States)

\section{SESSION 4B NOVEL SENSING FOR SHM}

765013 Structural health monitoring system for a power boiler [7650-37]

P. Gasior, J. Kaleta, Wroclaw Univ. of Technology (Poland); A. Przygoda, RAFAKO SA (Poland)

765014 Non-destructive measurement of the steel cable stress based on magneto-mechanical effect [7650-38]

W. Chen, L. Liu, P. Zhang, S. Hu, Chongqing Univ. (China)

765015 Development and characterization of antibacterial nanocomposite fiber based on PP/PET/nanosilver compatibilized with PP-g-MA [7650-39]

A. Barzegar, N. Golshan Ebrahimi, Tarbiat Modares Univ. (Iran, Islamic Republic of)

\section{SESSION 5A GUIDED WAVES IV: SIGNAL GENERATION AND ANALYSIS}

765016 Chirplet-based imaging using compact piezoelectric array [7650-40]

P. Masson, D. Langlois Demers, N. Quaegebeur, P. Micheau, Univ. de Sherbrooke (Canada)

765017 Acousto-elastic measurements and baseline-free assessment of bolted joints using guided waves in space structures [7650-41]

A. Zagrai, V. Gigineishvili, W. A. Kruse, A. Murray, New Mexico Institute of Mining and Technology (United States); D. Doyle, W. Reynolds, B. Arritt, H. Gardenier, Air Force Research Lab. (United States)

765018 Multiple debondings' detection in honeycomb sandwich structures using multi-frequency elastic guided waves [7650-42]

F. Song, G. L. Huang, J. H. Kim, Univ. of Arkansas at Little Rock (United States); S. Haran, Arkansas State Univ. (United States) 
765019 A low-power system design for Lamb wave methods [7650-43]

S. Deyerle, D. S. Ha, D. J. Inman, Virginia Polytechnic Institute and State Univ. (United States)

7650 1A Missile captive carry monitoring using a capacitive MEMS accelerometer [7650-44] B. Hatchell, F. Mauss, E. Santiago-Rojas, I. Amaya, J. Skorpik, K. Silvers, Pacific Northwest National Lab. (United States); S. Marotta, U.S. Army Aviation and Missile Research, Development and Engineering Ctr. (United States)

7650 1B Propulsion health monitoring of a turbine engine disk using spin test data [7650-45] A. Abdul-Aziz, Cleveland State Univ. (United States); M. Woike, NASA Glenn Research Ctr. (United States); N. Oza, B. Matthews, NASA Ames Research Ctr. (United States); G. Baakilini, NASA Glenn Research Ctr. (United States)

$76501 \mathrm{C}$ Positioning challenges in reconfigurable semi-autonomous robotic NDE inspection [7650-46] S. G. Pierce, G. Dobie, R. Summan, L. Mackenzie, Univ. of Strathclyde (United Kingdom); J. Hensman, K. Worden, The Univ. Of Sheffield (United Kingdom); G. Hayward, Univ. of Strathclyde (United Kingdom)

7650 1D An integrated health management system for real-time impact monitoring and prediction of impact-induced damage on composite structures [7650-47]

I. Mueller, Stanford Univ. (United States) and Karlsruhe Institute of Technology (Germany); S. Das, Acellent Technologies, Inc. (United States); S. Roy, V. Janapati, Stanford Univ. (United States); K. Vonnieda, Karlsruhe Institute of Technology (Germany); D. Zhang, Acellent Technologies, Inc. (United States); F.-K. Chang, Stanford Univ. (United States)

\section{SESSION 6A GUIDED WAVES V: MODELING}

$76501 \mathrm{E} \quad$ Efficient finite element modeling of scattering for 2D and 3D problems [7650-48]

P. D. Wilcox, A. Velichko, Univ. of Bristol (United Kingdom)

$7650 \mathrm{lF} \quad$ Frequency-domain bridging multiscale method for wave propagation simulations in damaged structures [7650-49]

F. Casadei, M. Ruzzene, Georgia Institute of Technology (United States)

$76501 G$ Transient ultrasonic wave field modeling in an elastic half-space using distributed point source method [7650-50]

S. Das, S. Banerjee, Acellent Technologies, Inc. (United States); T. Kundu, The Univ. of Arizona (United States)

$7650 \mathrm{1H}$ Modeling and characterization of macro-fiber composite transducers for Lamb wave excitation [7650-51]

M. Collet, FEMTO-ST, CNRS, Univ. de Franche-Comté (France); M. Ruzzene, K. Cunefare,

B. Xu, Georgia Institute of Technology (United States)

$765011 \quad$ Efficient methods to model the scattering of ultrasonic guided waves in 3D [7650-52]

L. Moreau, A. Velichko, P. D. Wilcox, Univ. of Bristol (United Kingdom) 
7650 1J Active sensing of fatigue damage using embedded ultrasonics [7650-53]

W. A. Kruse, A. Zagrai, V. Gigineishvili, New Mexico Institute of Mining and Technology (United States)

$7650 \mathrm{IL}$ Magneto elastic active sensors for structural health monitoring using magneto-mechanical impedance and elastic wave propagation [7650-55]

T. Barnes, D. Kukhalashvili, A. Zagrai, New Mexico Institute of Mining and Technology (United States)

\section{Part Two}

$76501 \mathrm{M}$ Influence of guided ultrasonic wave scattering directionality on the detection sensitivity for SHM of fatigue cracks [7650-56]

P. Fromme, Univ. College London (United Kingdom)

7650 iN Damage quantification using smart patch system for hot spot monitoring [7650-57]

S. Banerjee, S. J. Beard, Acellent Technologies, Inc. (United States); F. Habib, M. Martinez, National Research Council Canada (Canada)

\section{SESSION 7A SENSOR DEVELOPMENT}

765010 Magnetostrictive sleeve transducer for in situ monitoring of specimens [7650-58] M. J. Guers, B. R. Tittmann, The Pennsylvania State Univ. (United States)

7650 IP Development of a novel polymeric fiber-optic magnetostrictive metal detector [7650-59] W.-S. Hua, National Taiwan Univ. (Taiwan); J. R. Hooks, Univ. of Washington (United States); W.-J. Wu, National Taiwan Univ. (Taiwan); W.-C. Wang, Univ. of Washington (United States)

$76501 Q \quad$ Numerical investigation of cladding mode overlap of evanescent waves with air channels in index-guiding photonic crystal fiber long-period gratings [7650-60]

S. Zheng, Y. Zhu, S. Krishnaswamy, Northwestern Univ. (United States)

7650 1R A MEMS based measurement system for structure health monitoring applications [7650-61] S. Majcherek, S. Hirsch, B. Schmidt, Otto-von-Guericke-Univ. Magdeburg (Germany)

7650 is Development of a polymeric capacitive 3-D tactile sensor [7650-62] J.-H. Ho, National Taiwan Univ. (United States); A. Perez, W.-C. Wang, Univ. of Washington (United States)

7650 IT Surface acoustic wave generation and detection by Coulomb excitation [7650-63] A. Habib, Univ. Siegen (Germany); U. Amjad, M. Pluta, Univ. Leipzig (Germany); U. Pietsch, Univ. Siegen (Germany); W. Grill, Univ. Leipzig (Germany) 
$76501 \mathrm{~V}$ Structural health monitoring of helicopter hard landing using 3D digital image correlation [7650-65]

B. LeBlanc, C. Niezrecki, P. Avitabile, Univ. of Massachusetts Lowell (United States)

7650 IW Characterization of acoustic lenses with the Foucault test by confocal laser scanning microscopy [7650-66]

E. T. Ahmed Mohamed, A. Abdelrahman, M. Pluta, W. Grill, Univ. Leipzig (Germany)

7650 1X Paired structured light configuration for structural health monitoring [7650-67]

H. Myung, H. Jeon, S. Lee, S. H. Choi, KAIST (Korea, Republic of)

7650 IY Hardware complexity for extrinsic Fabry-Perot interferometer sensor processing [7650-68] W. J. Ebel, K. K. Mitchell, St. Louis Univ. (United States)

765012 Optical encoder feedback system for levitating rotor system [7650-69]

S. Khanna, J. N. Ho, J. Irwen, G. Rakka, W. Wang, Univ. of Washington (United States)

765020 Acousto-shearographic method for detecting adherence anomalies [7650-70]

O. Giraudo, ONERA (France); A. Damas, Cryospace (France)

\section{SESSION 8A GUIDED WAVES VI: STRESS MEASUREMENT}

765021 Stress dependence of guided waves in rails [7650-71]

I. Bartoli, S. Coccia, R. Phillips, A. Srivastava, F. Lanza di Scalea, S. Salamone, Univ. of California, San Diego (United States); M. Fateh, G. Carr, Federal Railroad Administration (United States)

765023 Guided wave propagation as a measure of axial loads in rails [7650-73]

P. W. Loveday, Council for Scientific and Industrial Research (South Africa); P. D. Wilcox, Univ. of Bristol (United Kingdom)

\section{SESSION 8B NEURAL NETWORK FOR SHM}

$765024 \quad$ Ultrasonic acoustic health monitoring of ball bearings using neural network pattern classification of power spectral density [7650-74]

W. Kirchner, S. Southward, M. Ahmadian, Virginia Polytechnic Institute and State Univ. (United States)

765026 Arch bridge suspender tension identification by using neural network [7650-76] D. Li, J. Ou, Dalian Univ. of Technology (China)

\section{SESSION 9A NOVEL DEVICES AND TECHNIQUES}

765028 Determination of the speed of ultrasound in thin materials by observation in reflection or transmission [7650-78]

U. Amjad, E. T. Ahmed Mohamed, A. Abdelrahman, W. Grill, Univ. Leipzig (Germany) 
765029 Experiments on focusing and use of acoustic energy to enhance the rate of polymer healing [7650-79]

E. A. Petersen, Univ. of Nebraska-Lincoln (United States); K. A. Barnes, B. C. Fehrman,

U. A. Korde, South Dakota School of Mines and Technology (United States)

7650 2A Determination of sound velocity and acoustic impedance of thin chitosan films by phase-sensitive acoustic microscopy [7650-80]

A. E. Kamanyi, E. T. Ahmed Mohamed, Univ. Leipzig (Germany); W. Ngwa, Univ. of Central Florida (United States); W. Grill, Univ. Leipzig (Germany)

\section{SESSION 9B VIBRATION-BASED SHM}

$76502 \mathrm{C}$ Bicoherence-based structural health monitoring of fixed offshore structures [7650-82] A. J. Hillis, Univ. of Bath (United Kingdom); C. R. P. Courtney, Univ. of Bristol (United Kingdom)

$76502 \mathrm{E}$ Machine learning algorithms to damage detection under operational and environmental variability [7650-84]

E. Figueiredo, Univ. do Porto (Portugal); G. Park, C. R. Farrar, Los Alamos National Lab. (United States); K. Worden, The Univ. of Sheffield (United Kingdom); J. Figueiras, Univ. do Porto (Portugal)

\section{SESSION 10A GUIDED WAVES VII: MODELING}

$76502 \mathrm{~F} \quad$ Generalized representations and universal aspects of Lamb wave dispersion relations [7650-85]

U. Amjad, K. S. Tarar, Univ. Leipzig (Germany); A. Shelke, T. Kundu, The Univ. of Arizona (United States); M. Pluta, W. Grill, Univ. Leipzig (Germany)

$76502 \mathrm{G}$ A time domain spectral element model for piezoelectric excitation of Lamb waves in isotropic plates [7650-86]

R. Mohamed, P. Masson, Univ. de Sherbrooke (Canada)

$76502 \mathrm{H} \quad$ Characterization of guided-wave propagation in composite plates [7650-87]

K. S. Nadella, K. I. Salas, C. E. S. Cesnik, Univ. of Michigan (United States)

765021 Quantitative modeling of dynamic behavior of a piezoelectric wafer actuator bonded to an elastic plate for guided wave propagation [7650-88]

G. L. Huang, F. Song, R. Reddy, Univ. of Arkansas at Little Rock (United States);

\section{SESSION 1OB BRIDGE MONITORING II}

$76502 \mathrm{~K} \quad$ Vulnerability analysis for design of bridge health monitoring system [7650-90] L. M. Sun, Tongji Univ. (China); G. Yu, Tongji Univ. (China) and Shanghai Municipal Engineering Design General Institute (China)

$76502 \mathrm{~L}$ Temperature effects on modal parameters and its experimental validation [7650-91] L. M. Sun, Z. H. Min, Tongji Univ. (China) 
$76502 \mathrm{~N}$ Time-series models for identifying damage location in structural members subjected to ambient vibrations [7650-93]

A. A. Mosavi, D. Dickey, R. Seracino, S. H. Rizkalla, North Carolina State Univ. (United States)

765020 A novel non-parametric sequential probability ratio test method for structural condition assessment [7650-94]

Z. H. Min, L. M. Sun, Tongji Univ. (China)

SESSION 11A GUIDED WAVES VIII: DAMAGE DETECTION

$76502 \mathrm{P}$ The influence of disbond defects on Lamb wave testing in GLARE composites [7650-95]

Q. Huang, B. Regez, S. Krishnaswamy, Northwestern Univ. (United States)

$76502 R \quad$ Understanding a reference-free impedance method using collocated piezoelectric transducers [7650-98]

E. J. Kim, Dong-A Univ. (Korea, Republic of); M. K. Kim, H. Sohn, KAIST (Korea, Republic of);

H. W. Park, Dong-A Univ. (Korea, Republic of)

$76502 S$ Sensor optimization for progressive damage diagnosis in complex structures [7650-99]

W. Zhou, N. Kovvali, A. Papandreou-Suppappola, A. Chattopadhyay, Arizona State Univ. (United States)

\section{SESSION 11B MEDICAL AND BIOLOGICAL APPLICATIONS}

7650 2T Micro patterning processes for thin film nitinol endografts and evaluation of endothelialization in swine model [7650-100]

Y. Chun, D. S. Levi, K. P. Mohanchandra, A. W. Tulloch, D. A. Rigberg, F. Vinuela,

F. Vinuela, Jr., G. P. Carman, Univ. of California, Los Angeles (United States)

$76502 \mathrm{U}$ Systematic approach to study of thinly and thickly sectioned melanoma tissues with scanning acoustic microscopy [7650-101]

C. Miyasaka, B. R. Tittmann, R. Tutwiler, The Pennsylvania State Univ. (United States); Y. Tian,

E. Maeva, Univ. of Windsor (Canada); D. Shum, Windsor Regional Hospital (Canada)

$76502 \mathrm{~V}$ Synchronous monitoring of muscle dynamics and muscle force for maximum isometric tetanus [7650-102]

M. Zakir Hossain, W. Grill, Univ. Leipzig (Germany)

$76502 \mathrm{~W}$ Warped frequency transform analysis of ultrasonic guided waves in long bones [7650-103]

L. De Marchi, E. Baravelli, Univ. of Bologna (Italy); K. Xu, D. Ta, Fudan Univ. (China);

A. Marzani, N. Speciale, E. Viola, Univ. of Bologna (Italy)

$76502 Z$ Design of effective in-silico adjusting method to support a doctor about the plan of administering medicine [7650-106]

Y. Kida, Ohu Univ. (Japan); T. Kida, Tokyo Institute of Technology (Japan) 
765030 Crack detection in glass plates using nonlinear acoustics with low-profile piezoceramic transducers [7650-107]

R. B. Jenal, W. J. Staszewski, The Univ. of Sheffield (United Kingdom)

765031 Effect of boundary conditions on nonlinear acoustics used for impact damage detection in composite structures [7650-109]

F. Aymerich, Univ. degli Studi di Cagliari (Italy); W. J. Staszewski, The Univ. of Sheffield (United Kingdom); T. Uhl, AGH Univ. of Science and Technology (Poland)

765032 Investigation of the threshold behavior of subharmonics for damage detection of a structure with a breathing crack [7650-108]

D. R. Johnson, K. W. Wang, Univ. of Michigan (United States); J.-S. Kim, Kumoh National Institute of Technology (Korea, Republic of)

\section{SESSION 13 NONLINEAR ANALYSIS AND TECHNIQUES II}

765034 Detection and localization of contact-type damages via nonlinear impedance modulation of piezoelectric materials bonded on a beam structure [7650-112]

A. Masuda, J. Aoki, D. Iba, A. Sone, Kyoto Institute of Technology (Japan)

765035 Dynamics characterization and health monitoring of membrane structures by time-frequency analysis [7650-113]

X. Qian, X. Du, Harbin Institute of Technology (China); P. F. Pai, Univ. of Missouri-Columbia (United States)

\section{SESSION 14 SENSOR NETWORK AND ARRAY}

765036 Autofocus for sparse array imaging [7650-114]

A. J. Croxford, A. J. Hunter, Univ. of Bristol (United Kingdom)

765037 Efficient imaging techniques using an ultrasonic array [7650-115]

L. Moreau, A. J. Hunter, B. W. Drinkwater, P. D. Wilcox, Univ. of Bristol (United Kingdom)

765038 Structural health monitoring of an impulsively loaded structure using wave-propagation based instantaneous baseline [7650-116]

J. C. Dodson, Virginia Polytechnic Institute and State Univ. (United States); J. R. Foley, Air Force Research Lab. (United States); D. J. Inman, Virginia Polytechnic Institute and State Univ. (United States)

7650 3A Combined distributed and concentrated transducer network for failure indication [7650-1 18] W. Ostachowicz, Institute of Fluid-Flow Machinery (Poland) and Gdynia Maritime Univ. (Poland); T. Wandowski, P. Malinowski, Institute of Fluid-Flow Machinery (Poland) 
7650 3B The phase transition method for SAR measurement in MRI [7650-119]

R. Romano, F. Acernese, S. Vilasi, F. Barone, Istituto Nazionale di Fisica Nucleare (Italy) and Univ. degli Studi di Salerno (Italy)

7650 3C MatCAKE: a flexible toolbox for integrating 2D NMR spectra in Matlab [7650-120]

R. Romano, F. Acernese, S. Vilasi, Univ. degli Studi di Salerno (Italy) and Istituto Nazionale di Fisica Nucleare (Italy); D. Paris, A. Motta, Istituto di Chimica Biomolecolare, CNR (Italy);

F. Barone, Univ. degli Studi di Salerno (Italy) and Istituto Nazionale di Fisica Nucleare (Italy)

7650 3D Biomedical imaging with THz waves [7650-121]

A. Nguyen, Univ. of California, Irvine (United States)

$76503 \mathrm{E}$ Investigation of THz for possible use in medical ultrasound technique [7650-122]

A. Nguyen, Univ. of California, Irvine (United States)

7650 3F Monitoring system of arch bridge for safety network management [7650-123]

B. C. Joo, Y. J. Yoo, C. H. Lee, K. T. Park, Y. K. Hwang, Korea Institute of Construction Technology (Korea, Republic of)

$76503 \mathrm{H}$ Structural damage detection based on non-negative matrix factorization and relevance vector machine [7650-127]

Y. Bao, H. Li, Y. Huang, Harbin Institute of Technology (China); J. Ou, Harbin Institute of Technology (China) and Dalian Univ. of Technology (China)

$765031 \quad$ Fractal theory and wavelet packet transform based damage detection method for beam structures [7650-128]

Y. Huang, Y. Yang, H. Li, Harbin Institute of Technology (China)

$76503 \mathrm{~J}$ Wave field characterization for non-destructive assessment of elastic properties using laser-acoustic sources in fluids and eye related tissues [7650-129]

T. Windisch, Fraunhofer-Institut für Zerstörungsfreie Prüfverfahren (Germany); and Carl Gustav Carus Univ. Hospital Dresden (Germany); F. Schubert, B. Köhler, Fraunhofer-Institut für Zerstörungsfreie Prüfverfahren (Germany); E. Spörl, Carl Gustav Carus Univ. Hospital Dresden (Germany)

Author Index 
Downloaded From: https://www.spiedigitallibrary.org/conference-proceedings-of-spie on 26 Apr 2023

Terms of Use: https://www.spiedigitallibrary.org/terms-of-use 


\title{
Conference Committee
}

\author{
Symposium Chairs
}

Donald J. Leo, Virginia Polytechnic Institute and State University (United States)

Kara J. Peters, North Carolina State University (United States)

Symposium Cochairs

Norbert G. Meyendorf, Fraunhofer-Institut für Zerstörungsfreie

Prüfverfahren (Germany) and University of Dayton (United States)

Norman M. Wereley, University of Maryland, College Park (United

States)

Conference Chair

Tribikram Kundu, The University of Arizona (United States)

Conference Cochair

Kumar V. Jata, Air Force Office of Scientific Research (Japan)

Program Committee

Douglas E. Adams, Purdue University (United States)

Sourav Banerjee, Acellent Technologies, Inc. (United States)

Yoseph Bar-Cohen, Jet Propulsion Laboratory (United States)

Fu-Kuo Chang, Stanford University (United States)

Victor Giurgiutiu, University of South Carolina (United States)

Olivier Giraudo, ONERA (France)

Wolfgang Grill, Universität Leipzig (Germany)

Shivan Haran, Arkansas State University (United States)

Guoliang Huang, University of Arkansas at Little Rock (United States)

Sridhar Krishnaswamy, Northwestern University (United States)

Francesco Lanza di Scalea, University of California, San Diego (United States)

Jerome P. Lynch, University of Michigan (United States)

Jennifer E. Michaels, Georgia Institute of Technology (United States)

Won-Bae Na, Pukyong National University (Korea, Republic of)

Perngjin F. Pai, University of Missouri, Columbia (United States)

Paul D. Panetta, Applied Research Associates, Inc. (United States)

Dominique Placko, École Normale Supérieure de Cachan (France)

Henrique L. Reis, University of Illinois at Urbana-Champaign (United States) 
Hoon Sohn, Korea Advanced Institute of Science and Technology (Korea, Republic of)

Michael D. Todd, University of California, San Diego (United States)

Wei-Chih Wang, University of Washington (United States)

Paul D. Wilcox, University of Bristol (United Kingdom)

Hwai-Chung Wu, Wayne State University (United States)

Andrei N. Zagrai, New Mexico Institute of Mining and Technology (United States)

George Zentai, Varian Medical Systems, Inc. (United States)

\section{Session Chairs}

la Guided Waves I: Signal Generation and Analysis

Tribikram Kundu, The University of Arizona (United States)

Wolfgang Grill, Universität Leipzig (Germany)

1b Bridge Monitoring

Won-Bae Na, Pukyong National University (Korea, Republic of)

Henrique L. Reis, University of Illinois at Urbana-Champaign (United States)

2a Guided Waves II: Signal Generation and Analysis

Jennifer E. Michaels, Georgia Institute of Technology (United States)

Anthony J. Croxford, University of Bristol (United Kingdom)

2b Signal Processing and Modeling

Andrei N. Zagrai, New Mexico Institute of Mining and Technology (United States)

Samik Das, Acellent Technologies, Inc. (United States)

3a Guided Waves III: Damage Detection

Hoon Sohn, KAIST (Korea, Republic of)

Francesco Lanza di Scalea, University of California, San Diego (United States)

3b Civil Structure and Pipe Monitoring

Henrique L. Reis, University of Illinois at Urbana-Champaign (United States)

Shivan Haran, Arkansas State University (United States)

4a Energy Harvesting and Low-powered Systems

Sourav Banerjee, Acellent Technologies, Inc. (United States)

Michael D. Todd, University of California, San Diego (United States) 
Perngjin F. Pai, University of Missouri-Columbia (United States)

Olivier Giraudo, ONERA (France)

5a Guided Waves IV: Signal Generation and Analysis

Francesco Lanza di Scalea, University of California, San Diego (United States)

Hoon Sohn, KAIST (Korea, Republic of)

5b Complete SHM System and Related Issues

Victor Giurgiutiu, University of South Carolina (United States)

Jennifer E. Michaels, Georgia Institute of Technology (United States)

6a Guided Waves V: Modeling

Anthony J. Croxford, University of Bristol (United Kingdom)

Guoliang Huang, University of Arkansas at Little Rock (United States)

6b Fatigue Damage Monitoring

Xilin P. Qing, Acellent Technologies, Inc. (United States)

7a Sensor Development

Wolfgang Grill, Universität Leipzig (Germany)

George Zentai, Varian Medical Systems, Inc. (United States)

7b Optical Techniques for SHM

Olivier Giraudo, ONERA (France)

Sridhar Krishnaswamy, Northwestern University (United States)

8a Guided Waves VI: Stress Measurement

Hoon Sohn, KAIST (Korea, Republic of)

Francesco Lanza di Scalea, University of California, San Diego (United States)

8b Neural Network for SHM

Michael D. Todd, University of California, San Diego (United States)

Andrei N. Zagrai, New Mexico Institute of Mining and Technology (United States)

9a Novel Devices and Techniques

Paul D. Panetta, Applied Research Associates, Inc. (United States)

9b Vibration-based SHM

Henrique L. Reis, University of Illinois at Urbana-Champaign (United States) 
10a Guided Waves VII: Modeling

Wolfgang Grill, Universität Leipzig (Germany)

Jennifer E. Michaels, Georgia Institute of Technology (United States)

10b Bridge Monitoring II

Shivan Haran, Arkansas State University (United States)

Paul D. Panetta, Applied Research Associates, Inc. (United States)

lla Guided Waves VIII: Damage Detection

Wolfgang Grill, Universität Leipzig (Germany)

Jennifer E. Michaels, Georgia Institute of Technology (United States)

$11 \mathrm{~b}$ Medical and Biological Applications

George Zentai, Varian Medical Systems, Inc. (United States)

Wei-Chih Wang, University of Washington (United States)

12 Nonlinear Analysis and Techniques I

Sridhar Krishnaswamy, Northwestern University (United States)

Paul D. Panetta, Applied Research Associates, Inc. (United States)

13 Nonlinear Analysis and Techniques II

Guoliang Huang, University of Arkansas at Little Rock (United States)

Joseph A. Turner, University of Nebraska-Lincoln (United States)

14 Sensor Network and Array

Henrique L. Reis, University of Illinois at Urbana-Champaign (United States)

Anthony J. Croxford, University of Bristol (United Kingdom) 


\section{Introduction}

In the year 2001, the SPIE conference (Conf. \#4335) on Health Monitoring of Structural and Biological Systems brought engineers, materials scientists, medical doctors, and biologists together to exchange their ideas on this important issue. After having a positive experience at that conference, yearly conferences were organized on the same topic and the next one has been planned for the year 2011. Proceedings \#7650 contain papers presented at the 2010 conference. Papers presented in the earlier conferences can be found in Proceedings \#4335 for 2001, \#4702 for 2002, \#5047 for 2003, \#5394 for 2004, \#5768 for 2005, \#6177 for 2006, \#6532 for 2007, \#6935 for 2008 and \#7295 for 2009.

The emphasis of this conference is to recognize that sensing by nondestructive evaluation, sensor array design, signal acquisition and transmission, signal processing, energy harvesting, etc. are integral parts of health monitoring for both structural and biological systems. I believe that biological and physical science communities are learning from each other by coming to this conference and exchanging ideas. Some of the recent advances in the science and technology of health monitoring techniques that go beyond the traditional nondestructive imaging of internal defects are presented in these proceedings. New diagnosis, prognosis and rehabilitation techniques applied to engineering structures made of metal, concrete, and composites, as well as biological systems, are presented. The papers published here cover a wide range of technologies. It is hoped that this conference will stimulate further interactions between physical and life science community resulting in newer development of more innovative techniques for health monitoring applications.

I am thankful to the conference co-chair, program committee members, authors, session chairs, and the SPIE staff for putting together this excellent conference.

Tribikram Kundu 
Downloaded From: https://www.spiedigitallibrary.org/conference-proceedings-of-spie on 26 Apr 2023

Terms of Use: https://www.spiedigitallibrary.org/terms-of-use 